\title{
Penggunaan Indikator Kubis Ungu pada Analisis Asam Lemak Bebas dengan Metode Titrasi
}

\author{
Riniati $^{\mathrm{a}^{*}}$, Dewi Widyabudiningsih ${ }^{\mathrm{a}}$, Ahya Sularasa ${ }^{\mathrm{a}}$ \\ a Program Studi D-3 Analis Kimia, Jurusan Teknik Kimia Politeknik Negeri Bandung \\ * corresponding author riniati@poban.ac.id \\ DOI : 10.20885/ijca.vol3.iss2.art3
}

\section{ARTIKEL INFO}

Diterima : 13 Agustus 2020

Direvisi : 30 Agustus 2020

Diterbitkan : 09 September 2020

Kata kunci : kubis ungu, indikator asam - basa, sokletasi, titrasi, asam lemak bebas

\begin{abstract}
ABSTRAK
Penggunaan indikator alami dalam titrasi asam-basa dapat dijadikan salah satu materi pengenalan senyawa kimia bahan alam dalam metode analisis kimia. Kubis ungu (Brassica oleracea) merupakan salah satu alternatif bahan pembuatan indikator asam basa alami karena memiliki senyawa antosianin yang memberikan warna berbeda pada derajat keasaman $(\mathrm{pH})$ yang berbeda. Tujuan penelitian ini untuk mengekstrak antosianin yang terdapat dalam kubis ungu selanjutnya diaplikasikan sebagai indikator titrasi asam-basa. Penelitian diawali dengan preparasi bahan baku kubis ungu, dilanjutkan dengan ekstraksi metode sokletasi menggunakan pelarut metanol. Ekstrak yang didapat didistilasi pada suhu titik didih pelarutnya hingga kepekatan ekstrak 50\%. Ekstrak kubis ungu digunakan sebagai indikator dalam menentukan asam lemak bebas menggunakan sampel asam oleat. Sebagai standar pembanding indikator digunakan indikator fenolphtalein. Perubahan warna indikator kubis ungu dari merah muda ke hijau toska dengan kisaran pH 6 - 9. Penggunaan indikator kubis ungu dengan pelarut metanol dalam penentuan asam oleat menunjukkan hasil yang mendekati indikator fenolphtalein, yaitu nilai koefisien korelasi (R) adalah 0,9996. Pengujian \% recovery menggunakan indikator ekstrak kubis ungu dapat diterima, yaitu 100,50\%. Dengan demikian indikator ini layak digunakan sebagai indikator asam-basa pada analisa asam lemak bebas seperti halnya indikator fenolftalein sintetik yang biasa digunakan.
\end{abstract}

\begin{tabular}{|c|c|}
\hline ARTICLE INFO & $A B S T R A C T$ \\
\hline $\begin{array}{l}\text { Received : } 13 \text { August } 2020 \\
\text { Revised : } 30 \text { August } 2020 \\
\text { Published : 09 September } 2020 \\
\text { Keywords : Purple cabbage, Acid- } \\
\text { base indicator, Soxhletation, } \\
\text { Titration, Free fatty acids }\end{array}$ & $\begin{array}{l}\text { The use of natural indicators in acid-base titrations can be used as a } \\
\text { material for introducing the use of natural chemical compounds in } \\
\text { chemical analysis methods. Purple cabbage (Brassica oleracea) is an } \\
\text { alternative material for making natural acid-base indicators because it } \\
\text { has anthocyanin compounds that give different colors to different degrees } \\
\text { of acidity (pH). The purpose of this study was to extract the anthocyanin } \\
\text { contained in purple cabbage and then applied it as an indicator of acid- } \\
\text { base titration. The research began with the preparation of purple cabbage } \\
\text { as raw material, followed by the extraction of the soxhletation method } \\
\text { using methanol as a solvent. The extract obtained was distilled at the } \\
\text { boiling point temperature of the solvent to the extract concentration of } \\
50 \% \text {. The purple cabbage extract was used as an indicator in determining } \\
\text { free fatty acids using oleic acid samples. The phenolphthalein indicator } \\
\text { was used as a standard comparison indicator. The color change of the } \\
\text { purple cabbage indicator from pink to turquoise with a pH range of } 6 \text { - } 9 . \\
\text { The use of the purple cabbage indicator with methanol as a solvent in the } \\
\text { determination of oleic acid showed results that were close to the } \\
\text { phenolphthalein indicator, namely the correlation coefficient (R) was } \\
0.9996 \text {. The \% recovery test result using the purple cabbage extract } \\
\text { indicator is acceptable, which is } 100.50 \% \text {. Thus, this indicator is suitable } \\
\text { for use as an acid-base indicator in the analysis of free fatty acids as well } \\
\text { as synthetic phenolphthalein indicators that are commonly used. }\end{array}$ \\
\hline
\end{tabular}




\section{PENDAHULUAN}

Metode titrasi merupakan metode konvensional yang umum dilakukan di laboratorium kimia untuk melakukan analisis berbagai jenis sampel diantaranya penentuan asam lemak bebas dalam minyak. Menurut SNI Nomor 01-3555-1988 tentang uji minyak dan lemak dengan metode titrasi, indikator yang digunakan pada analisa tersebut yaitu fenolphtalein [1]. Penggunaan indikator sintetis memiliki kekurangan seperti menyebabkan pencemaran lingkungan, harganya yang relatif mahal dan pemesanan yang cukup lama. Salah satu cara untuk mengatasi permasalahan tersebut adalah dengan menggunakan indikator alami yang berasal dari pigmen tumbuhan, baik dari bunga, daun, buah atau kulit. Sayuran atau buah yang berwarna seperti biru, merah, ungu, atau orange umumnya mengandung senyawa fenolik antosianin [2]. Adanya kandungan antosianin dalam tanaman menjadi salah satu alternatif penggunaan indikator $\mathrm{pH}$ alami yang efektif dibanding zat warna lain [3].

Kubis ungu (red cabbage) seperti tampak pada Gambar 1, termasuk dalam satu familia Brassica oleracea yang dapat dijadikan sebagai alternatif bahan pembuatan indikator asam basa alami karena memiliki senyawa antosianin. Ekstrak antosianin dari kubis ungu dengan pelarut $\mathrm{HCl}$ dalam metanol menunjukkan kadar antosianin paling lengkap yang memiliki perubahan warna hampir pada semua rentang $\mathrm{pH}$. Senyawa ini dapat berubah warna pada suasana asam maupun basa sehingga memungkinkan ekstrak kubis ungu dapat digunakan sebagai indikator alami titrasi asam basa [4]. Profil antosianin kubis ungu terdiri dari dua puluh turunan dari sianidin glukosida dijelaskan melalui HPLC-DAD-MS/MS. Struktur dasar antosianin yang diidentifikasi adalah sanidin-3-diglukosida-5-glucosida [5].

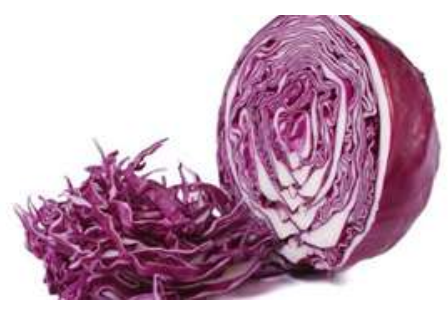

Gambar 1. Kubis ungu

Warna antosianin sangat dipengaruhi oleh struktur antosianin serta derajat keasaman $(\mathrm{pH})$. Antosianin cenderung tidak berwarna di daerah $\mathrm{pH}$ netral, di dalam larutan yang pHnya sangat asam $(\mathrm{pH}<3)$ memberikan warna merah yang maksimum, sedangkan di dalam larutan alkali $(\mathrm{pH}$ 10,5 ) pigmen antosianin mengalami perubahan warna menjadi biru [6]. Zat warna antoisanin kubis ungu adalah sejenis pigmen alami diekstrak dari kubis ungu yang ramah lingkungan. Struktur antosianin dari kubis ungu dipengaruhi oleh $\mathrm{pH}$ dan mengalami transformasi seperti yang ditunjukkan pada Gambar 2 [7]. Trayek $\mathrm{pH}$ Ekstrak kubis ungu dengan pelarut etanol berada pada kisaran $\mathrm{pH}$ 6,50-7,50 (Ungu-Biru), $\mathrm{pH}$ 10,50-12,00 (hijau-hijau kebiruan) dan $\mathrm{pH}$ 12,00-13,00 (Hijau kebiruan-Kuning) [8].

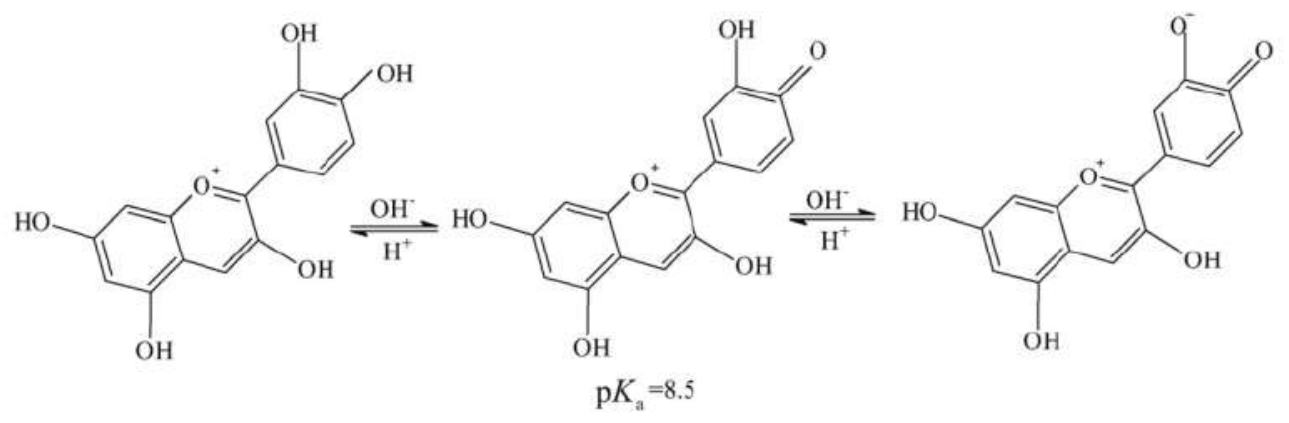

Gambar 2. Struktur antosianin pada kondisi perubahan $\mathrm{pH}[7]$. 
Ekstraksi senyawa antosianin dapat dilakukan dengan metode sokletasi menggunakan pelarut tertentu. Metode sokletasi menggunakan suatu pelarut yang mudah menguap dapat melarutkan senyawa antosianin yang terdapat dalam kubis ungu, tetapi tidak melarutkan zat padat yang tidak diinginkan. Pelarut metanol terbukti dapat mengekstrak antosianin dalam kembang sepatu memberikan hasil ekstrak yang baik sebagai indikator asam-basa [9]. Hal ini yang mendasari pemilihan pelarut metanol dalam ekstraksi sokletasi. Penelitian ini bertujuan untuk memanfaatkan potensi kubis ungu sebagai bahan indikator asam basa dan menerapkannya dalam analisa asam lemak bebas. Hal ini diharapkan agar kubis ungu lebih optimal sebagai bahan alternatif indikator asam basa alami dalam menentukan keasaman suatu sampel. Ekstrak kubis ungu diujikan secara volumetri sebagai indikator pada titrasi $\mathrm{HCl}-\mathrm{NaOH}$ dan diujikan terhadap sampel asam lemak bebas dalam hal ini menggunakan asam oleat. Pengujian meliputi penentuan koefisien korelasi dan $\%$ recovery.

\section{METODE}

\subsection{Alat}

Peralatan yang digunakan meliputi alat-alat ekstraksi dan alat-alat titrasi. Alat ekstraksi yaitu tabung soklet, kondensor spiral, labu distilasi, heating mantle dan selang. Alat-alat titrasi seperti buret, labu Erlenmeyer, labu seukuran, pipet seukuran, corong, batang pengaduk, botol timbang, botol semprot, gelas kimia, klem buret, pipet tetes dan statif. Alat pendukung analisis lain yaitu kromatografi lapis tipis (KLT), spektrofotometer FTIR dan UV-VIS.

\subsection{Bahan}

Bahan-bahan yang dibutuhkan yaitu: kubis ungu segar, metanol, larutan $\mathrm{HCl}$ dan $\mathrm{NaOH}$ dengan konsentrasi kurang lebih $0,1 \mathrm{~N}$ yang distandarisasi; indikator fenolftalein, asam oksalat p.a, aquades, larutan buffer $\mathrm{pH}$ 1-14, sampel asam oleat (teknis).

\subsection{Prosedur Kerja}

\subsubsection{Ekstraksi Kubis Ungu dengan Sokletasi}

Ditimbang sebanyak $40 \mathrm{~g}$ kubis ungu kemudian dicuci dengan air dan dikeringkan di udara terbuka selama kurang lebih 2 jam. Selanjutnya dipotong-potong dengan ukuran kurang lebih $1 \mathrm{~cm}$ dan dibungkus dengan kertas saring kemudian dimasukkan ke dalam alat soklet. Selanjutnya dilakukan sokletasi dengan menambahkan pelarut metanol sebanyak $80 \mathrm{~mL}$ [10] dan diekstraksi selama 2 jam (kurang lebih lima belas siklus). Ekstraksi dilakukan pada suhu $68^{\circ} \mathrm{C}$ mendekati suhu optimum maserasi untuk menghasilkan kadar antosianin yaitu pada suhu $60^{\circ} \mathrm{C}$ [11]. Filtrat hasil ektraksi didestilasi sampai volume menjadi setengahnya (50\%). Ekstrak kubis ungu siap digunakan sebagai indikator titrasi asam-basa.

\subsubsection{Karakterisasi antosianin ekstrak kubis ungu}

Karakterisasi ekstraks kubis ungu meliputi analisis spektrum FTIR, UV-VIS dan nilai Rf kromatografi lapis tipis (KLT).

\subsubsection{Pengujian kuantitatif titrasi asam oleat menggunakan indikator kubis ungu dengan pembanding indikator fenolphtalein \\ a. Uji Pendahuluan titrasi $\mathrm{HCl}$ - NaOH}

Dipipet sebanyak $10 \mathrm{~mL}$ larutan $\mathrm{NaOH} 0,1 \mathrm{~N}$ yang sudah distandarisasi, lalu dimasukkan dalam erlenmeyer, kemudian ditambah 6 tetes indikator ekstrak kubis ungu, selanjutnya dititrasi dengan larutan $\mathrm{HCl} 0,1 \mathrm{~N}$ standar sampai terjadi perubahan warna. Titrasi dilakukan triplo terhadap 6 sampel berbeda dengan konsentrasi yang diketahui menggunakan indikator fenolftalein sebagai pembanding. Dari data pengujian dihitung linearitas dan \% recovery.

\section{b. Titrasi sampel asam oleat}

Sebanyak 14 gram sampel asam oleat ditimbang pada tiap tahap dan dimasukkan ke dalam Erlenmeyer $250 \mathrm{~mL}$ kemudian ditambahkan $25 \mathrm{~mL}$ etanol 95\% dan 6 tetes indikator kubis ungu. 
Selanjutnya dititrasi dengan $\mathrm{NaOH} 0,1 \mathrm{~N}$ yang telah distandarisasi seperti halnya uji linearitas pada titrasi $\mathrm{HCl}$ atau $\mathrm{NaOH}$. Setiap titrasi dilakukan secara duplo atau triplo.

\section{HASIL PENELITIAN}

\subsection{Hasil Ekstraksi}

Pelarut polar yang umum digunakan dalam ekstraksi antosianin kubis ungu dengan metode padat cair (sokletasi) yaitu alkohol (metanol/etanol). Diketahui kandungan antosianin dalam kubis ungu yang dihasilkan dengan metode ini cukup tinggi, yaitu $62.94(\mathrm{mg} / 100 \mathrm{~g})$ [1]. Ekstraksi antosianin dari kubis ungu dengan metode sokletasi menggunakan pelarut metanol menghasilkan ekstrak berwarna merah dengan konsentrasi ekstrak $50 \%(\mathrm{~b} / \mathrm{v})$. Uji kualitatif perubahan warna indikator pada berbagai larutan buffer $\mathrm{pH}$ (1-14) menunjukkan perubahan warna yang jelas dari merah muda ke hijau (toska) pada rentang pH 6-9 seperti ditunjukkan pada Gambar 3.
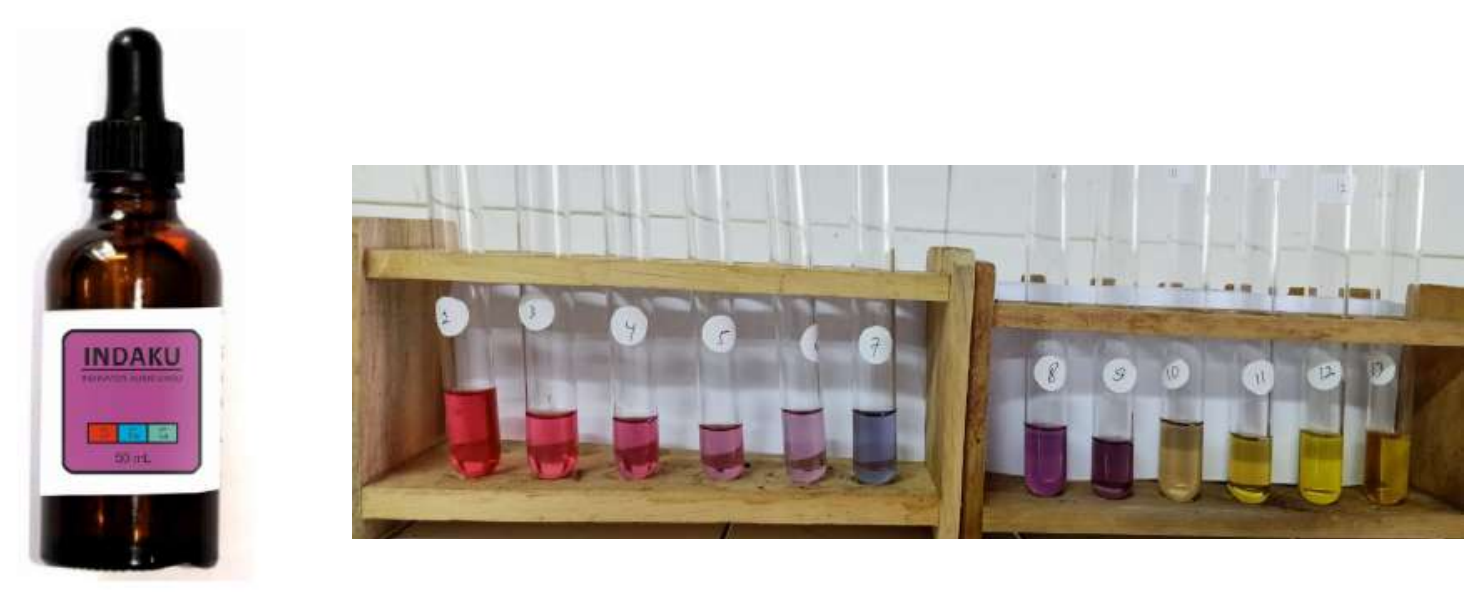

Gambar 3. Indikator Kubis ungu ("INDAKU") dan perubahan warna pada pH 1-13

\subsection{Spektrum FTIR, UV-VIS dan KLT ekstrak kubis ungu}

Pengujian kualitatif gugus fungsi senyawa yang terdapat pada ekstrak kubis ungu menggunakan FTIR ditunjukkan pada Gambar 4, terlihat kemiripan spektrum ekstrak kubis ungu jika dibandingkan dengan spektrum antosianin secara umum [10]. Terdapat puncak spektrum pada bilangan gelombang pada $16003500,1600,1000 \mathrm{~cm}^{-1}$.

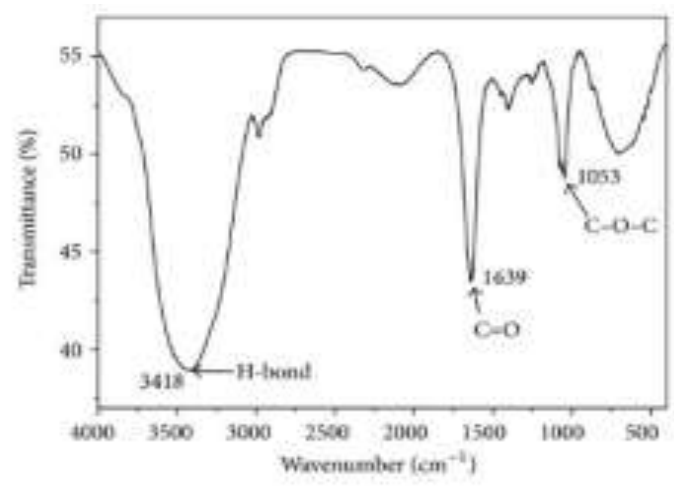

(a) Spektrum FTIR antosianin [10]

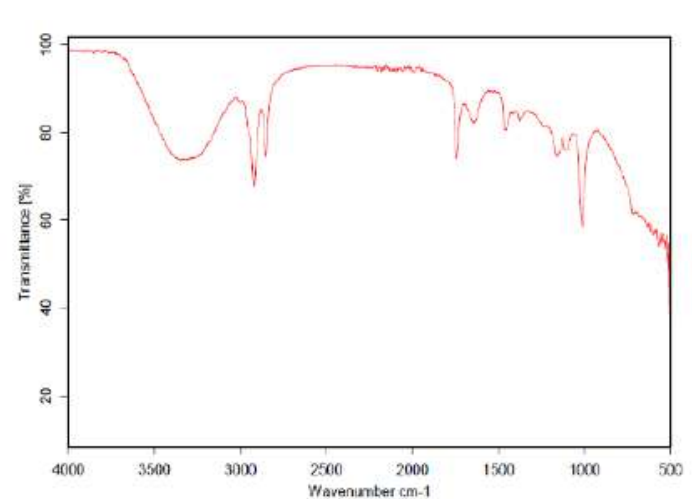

(b) Ekstrak Kubis ungu

Gambar 4. Spektrum FTIR antosianin (a) dan kubis ungu (b) 
Pengujian spektrum UV-VIS tampak pada Gambar 5, serapan maksimum ekstrak antosianin yaitu pada panjang gelombang $536 \mathrm{~nm}$. Hal sesuai dengan panjang gelombang maksimum standar penentuan kadar antosianin yang biasa dilakukan [12]. Ini menunjukkan bahwa hasil ekstrak kubis ungu terbukti mengandung senyawa antosianin.

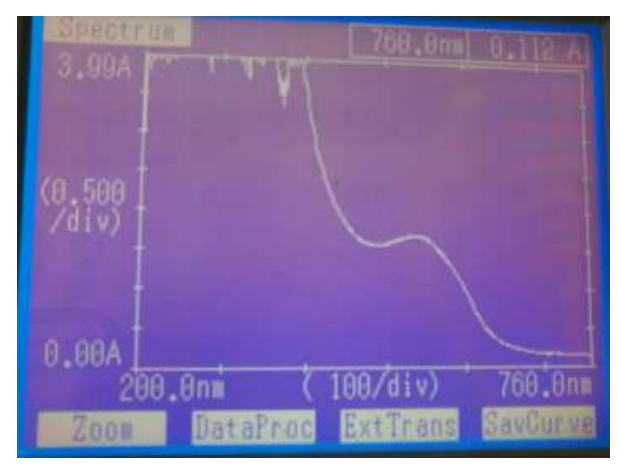

Gambar 5. Spektrum UV-VIS ekstrak kubis ungu

Identifikasi senyawa antosianin dalam ekstrak kubis ungu menggunakan kromatografi lapis tipis menggunakan fasa ferak butanol:asam asetat:air dengan perbandingan $(4: 1 ; 2) \mathrm{v} / \mathrm{v}$. Fasa diam yang digunakan adalah silika gel dengan jarak perambatan $17 \mathrm{~cm}$. Dari hasil KLT seperti pada Gambar 6 terlihat adanya bercak berwarna biru terang dengan nilai Rf 0,50 dan 0,76 pada sinar UV 366 $\mathrm{nm}$, hal ini meyakinkan dugaan positif antosianin [13].

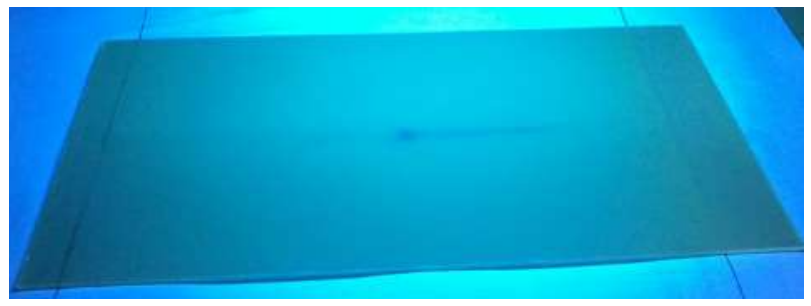

Gambar 6. Plat KLT antosianin ekstrak kubis ungu pada $\chi 366 \mathrm{~nm}$

\subsection{Uji Kuantitatif secara volumetri}

Uji pendahuluan presisi dan akurasi terhadap indikator kubis ungu dilakukan dengan titrasi $\mathrm{NaOH}$ dan $\mathrm{HCl}$ menggunakan pembanding indikator fenolftalein. Pengerjaan dilakukan sebanyak 6 (enam) kali pada variasi konsentrasi $\mathrm{HCl}$ yang berbeda (Tabel.1). Berdasarkan hasil pengujian yang dilakukan, diperoleh nilai koefisien korelasi menggunakan indikator fenolftalein yaitu sebesar $\mathrm{R}=$ 0,9997 sedangkan nilai koefisien korelasi menggunakan indikator ekstrak kubis ungu menggunakan pelarut metanol diperoleh $\mathrm{R}=0,9995$ (Gambar 7).

TABEL.1 Titrasi $10 \mathrm{~mL} \mathrm{HCl}$ terhadap $\mathrm{NaOH}$ 0,0981 N menggunakan indikator fenolphtalein dan kubis ungu

\begin{tabular}{ccc}
\hline $\begin{array}{c}\text { Konsentrasi HCl (N) } \\
\text { (yang diketahui) }\end{array}$ & $\begin{array}{c}\text { Konsentrasi HCl (N) } \\
\text { yang terukur } \\
\text { ( indikator fenolphtalein) }\end{array}$ & $\begin{array}{c}\text { Konsentrasi HCl (N) } \\
\text { yang terukur } \\
\text { (indikator kubis ungu) }\end{array}$ \\
\hline 0,0050 & 0,0057 & 0,0062 \\
0,0100 & 0,0103 & 0,0108 \\
0,0200 & 0,0196 & 0,0201 \\
0,0400 & 0,0400 & 0,0400 \\
0,0600 & 0,0589 & 0,0596 \\
0,0800 & 0,0785 & 0,0795 \\
\hline
\end{tabular}




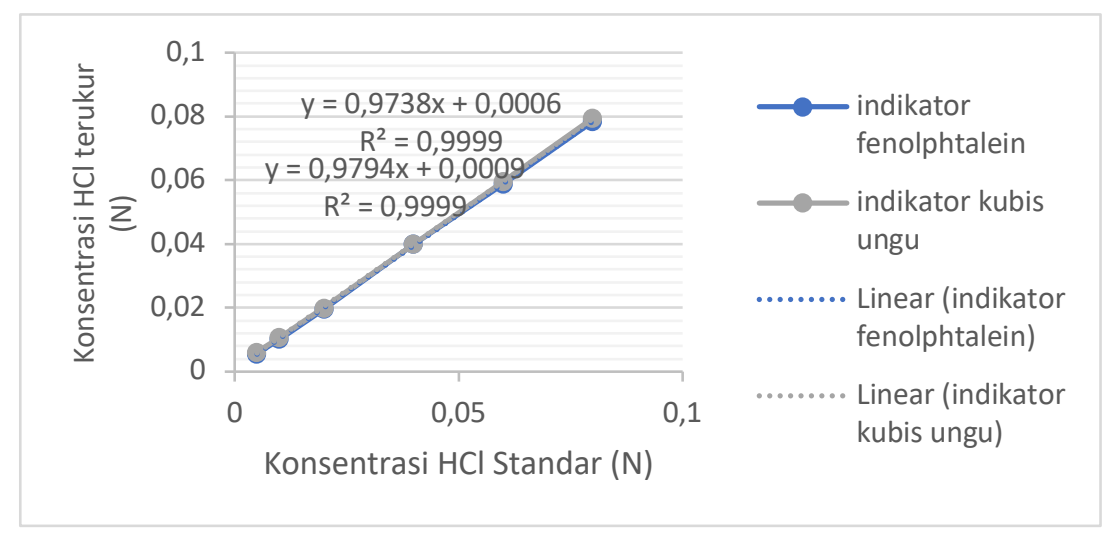

Gambar 7. Kurva linieritas titrasi $\mathrm{HCl}$ - $\mathrm{NaOH}$ menggunakan indikator kubis ungu dengan pembanding indikator fenolphtalein

Aplikasi penggunaan indikator kubis ungu dalam penentuan asam lemak bebas menunjukkan hasil akurasi dan presisi mendekati indikator standar (Tabel 2 dan Gambar 8). Perubahan warna titik akhir titrasi(TA) dari warna merah ke hijau toska. Untuk sampel asam oleat, warna TA sedikit lebih muda dibandingkan sampel $\mathrm{HCl}$ seperti tampak pada Gambar 9 dan 10 . Menurut guidance for method validation in chemical analysis CIPAC 2010 bahwa pengukuran dapat diterima karena koefisien korelasi mendekati 1. Hal ini menunjukkan bahwa indikator kubis ungu sangat relavan digunakan sebagai indikator menggantikan indikator sintetik fenolphtalein yang biasa digunakan.

TABEL II. Tittrasi asam oleat dengan $\mathrm{NaOH} 0,5556 \mathrm{~N}$ menggunakan indkator kubis ungu dan pembanding indikator fenolphtaklein

\begin{tabular}{ccc}
\hline Berat asam oleat $(\mathrm{g})$ & $\begin{array}{c}\text { mmol asam oleat } \\
\text { (indikator fenolphtalein) }\end{array}$ & $\begin{array}{c}\text { mmol asam oleat } \\
\text { (indikator kubis ungu) }\end{array}$ \\
\hline 0,82 & 3,64 & 3,53 \\
1,32 & 5,61 & 5,54 \\
1,82 & 7,35 & 7,45 \\
2,32 & 9,83 & 9,70 \\
2,82 & 11,85 & 11,91 \\
3,12 & 13,72 & 13,68 \\
\hline
\end{tabular}

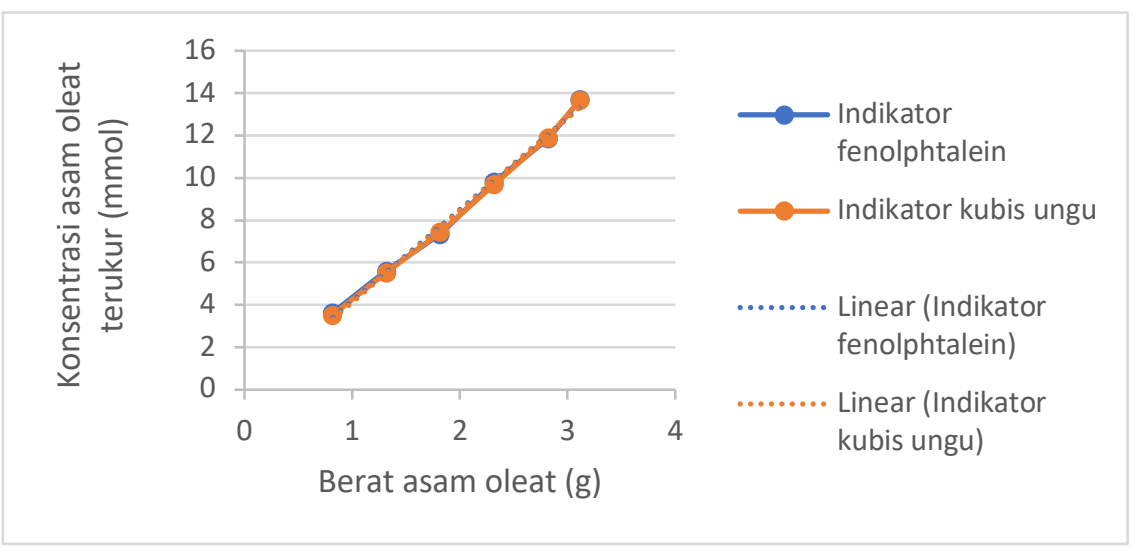

Gambar 8. Kurva linieritas titrasi asam oleat dengan $\mathrm{NaOH}$ menggunakan indikator kubis ungu dengan pembanding indikator fenolphtalein 


\section{4. \% Recovery Indikator Kubis Ungu dalam Titrasi Asam Basa}

Dari pengujian yang dilakukan diperoleh nilai \% recovery dari indikator ekstrak kubis ungu sebesar 100.28\%. Nilai ini didapat dari hasil titrasi $10 \mathrm{~mL} \mathrm{HCl} \mathrm{0,096} \mathrm{N}$ dengan $\mathrm{NaOH} \mathrm{0,094} \mathrm{N}$ menggunakan indikator kubis ungu dan pembanding indikator fenolphtalein (Tabel 3). Sedangkan $\%$ recovery titrasi asam oleat dengan larutan standar $\mathrm{NaOH}$ menggunakan indikator kubis ungu sebesar 100,50 (Tabel 4). Menurut guidance for method validation in chemical analysis CIPAC 2010 bahwa jika nilai \%w/w analit sekitar $0.1-1, \%$ recovery yang diterima yaitu 85-115. Maka dapat disimpulkan pengujian \% recovery menggunakan indikator ekstrak kubis ungu dengan pelarut metanol dapat diterima.
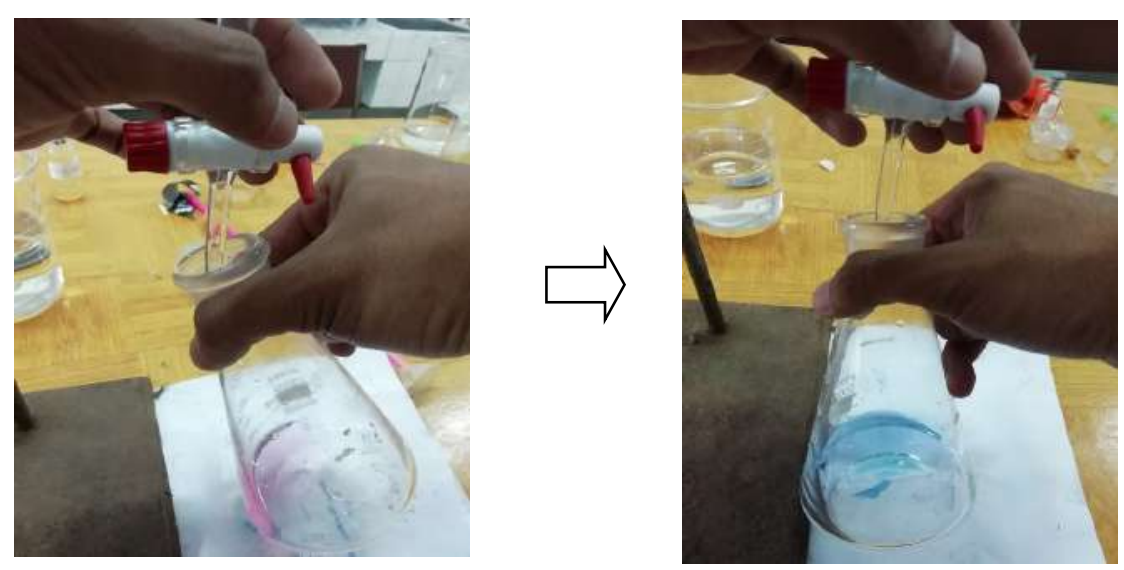

Gambar 9. Perubahan warna titik akhir titrasi (TA) $\mathrm{HCl}$ dengan $\mathrm{NaOH}$ menggunakan indikator kubis ungu (TA; hijau toska)
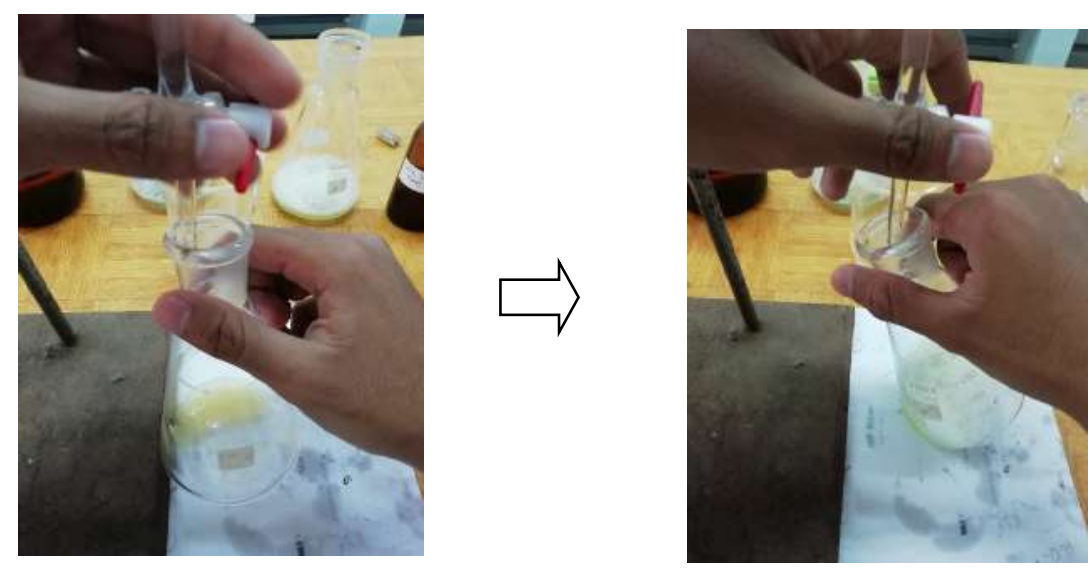

Gambar 10. Perubahan warna TA titrasi sampel asam oleat dengan $\mathrm{NaOH}$ menggunakan indikator kubis ungu (TA; hijau toska)

TABEL. III. \% recovery titrasi $\mathrm{HCl}$ dengan $\mathrm{NaOH}$ 


\begin{tabular}{|c|c|c|c|c|c|c|c|c|c|}
\hline \multicolumn{10}{|c|}{ Volume $\mathrm{HCl}(\mathrm{mL})$ pada titrasi ke } \\
\hline Indikator & I & II & III & IV & V & VI & VII & Rata-rata & \%recovery* \\
\hline Fenolphtalein & 10,40 & 10,40 & 10,45 & 10,40 & 10,40 & 10,45 & 10,45 & 10,42 & 100,00 \\
\hline Kubis Ungu & 10,45 & 10,50 & 10,45 & 10,45 & 10,45 & 10,45 & 10,40 & 10,45 & 100,28 \\
\hline \multicolumn{10}{|c|}{$* \%$ Recovery $=(\mathrm{C}$ pengukuran/ C sebenarnya $) \times 100 \%$} \\
\hline \multicolumn{10}{|c|}{$\begin{array}{l}\text { TABEL IV. \% Recovery Titrasi 2,82 gram Asam Oleat dengan NaOH 0, 0,5556 N menggunak } \\
\text { Indikator Fenolphtalein dan Kubis Ungu }\end{array}$} \\
\hline \multirow{2}{*}{ Titrasi } & \multicolumn{9}{|c|}{ Konsentrasi asam oleat (mmol) } \\
\hline & I & II & III & IV & $\mathrm{V}$ & VI & VII & rata-rata & $\begin{array}{c}\% \\
\text { recovery }\end{array}$ \\
\hline $\begin{array}{l}\text { Indikator } \\
\text { Fenolphtalein }\end{array}$ & 11,83 & 11,86 & 11,89 & 11,83 & 11,86 & 11,89 & 11,86 & 11,86 & 100,00 \\
\hline Kubis Ungu & 11,89 & 11,92 & 11,92 & 11,89 & 11,95 & 11,92 & 11,95 & 11,92 & 100,50 \\
\hline
\end{tabular}

\section{KESIMPULAN}

Berdasarkan penelitian ini, dapat disimpulkan, bahwa ekstrak kubis ungu dengan pelarut metanol dapat digunakan sebagai indikator titrasi asam lemak bebas dengan perubahan warna dari merah ke hijau pada range $\mathrm{pH}$ 6-9. Dari hasil pengujian terhadap titrasi asam oleat dengan penitrasi $\mathrm{NaOH}$ diperoleh nilai koefisien korelasi $\mathrm{R}=0.9966$ dan nilai \% recovery dari indikator ekstrak kubis ungu sebesar $100,50 \%$, dimana nilai tersebut memenuhi standar metode validasi analisis kimia. Dengan demikian indikator ini layak untuk digunakan sebagai pengganti indikator fenolftalein pada titrasi asam basa termasuk titrasi asam lemak bebas.

\section{Acknowledgment}

Penulis mengucapan terimakasih kepada Unit Penelitian dan Pengabdian Masyarakat (UPPM) POLBAN yang telah memberikan dana untuk penelitian ini melalui dana Penelitian Kapasitas Laboratorium 2019.

\section{Daftar Pustaka}

[1] A. Demirdöven, K. Özdoğan, and K. Erdoğan-Tokatli, "Extraction of Anthocyanins from Red Cabbage by Ultrasonic and Conventional Methods: Optimization and Evaluation," J. Food Biochem., vol. 39, no. 5, pp. 491-500, 2015, doi: 10.1111/jfbc. 12153 .

[2] H. Rymbai, R. R. Sharma, and M. Srivastav, "Sbiocolorants and its implications in health and food industry - a review," Int. J. PharmTech Res., vol. 3, no. 4, pp. 2228-2244, 2011.

[3] Z. Yang, H. Peng, W. Wang, and T. Liu, "Crystallization behavior of poly( $\varepsilon$-caprolactone)/layered double hydroxide nanocomposites," J. Appl. Polym. Sci., vol. 116, no. 5, pp. 2658-2667, 2010, doi: 10.1002/app.

[4] B. Santoso and E. W. Sri Mulyono, "Penapisan Zat Warna Alam Golongan Anthocyanin dari Tanaman Sekitar Sebagai Indikator Asam Basa," Fluida, vol. 11, no. 2, pp. 1-8, 2017, doi: 10.35313/fluida.v11i2.80.

[5] W. Wiczkowski, D. Szawara-Nowak, and J. Topolska, "Red cabbage anthocyanins: Profile, isolation, identification, and antioxidant activity," Food Res. Int., vol. 51, no. 1, pp. 303-309, 2013, doi: 10.1016/j.foodres.2012.12.015.

[6] M. and A. Torskangerpoll, Qyvind, "Colour stability of anthocyanins in aqulous solutions at various 
pH values," J. Food Chem., vol. 89, pp. 427-444, 2004.

[7] X. Chen and Z. Gu, "Absorption-type optical pH sensitive film based on immobilized purple cabbage pigment," Sensors Actuators, B Chem., vol. 178, pp. 207-211, 2013, doi: 10.1016/j.snb.2012.12.094.

[8] N. Gustriani, K. Novitriani, and U. Mardiana, "PENENTUAN TRAYEK pH EKSTRAK KUBIS UNGU (Brassica oleracea L) SEBAGAI INDIKATOR ASAM BASA DENGAN VARIASI KONSENTRASI PELARUT ETANOL,” J. Kesehat. Bakti Tunas Husada J. Ilmu-ilmu Keperawatan, Anal. Kesehat. dan Farm., vol. 16, no. 1, p. 94, 2016, doi: 10.36465/jkbth.v16i1.171.

[9] R. Riniati, A. Sularasa, and A. D. Febrianto, "Ekstraksi Kembang sepatu (Hibiscus Rosa Sinensis L) Menggunakan Pelarut Metanol dengan Metode Sokletasi untuk Indikator Titrasi Asam Basa," IJCA (Indonesian J. Chem. Anal., vol. 2, no. 01, pp. 34-40, 2019, doi: 10.20885/ijca.vol2.iss1.art5.

[10] H. Chang, M. J. Kao, T. L. Chen, C. H. Chen, K. C. Cho, and X. R. Lai, "Characterization of natural dye extracted from wormwood and purple cabbage for dye-sensitized solar cells," Int. J. Photoenergy, vol. 2013, 2013, doi: 10.1155/2013/159502.

[11] R. E. E. Susanti, A. Nurjanah, R. E. Safitri, and Q. A'yun, "Pemanfaatan Ekstrak Kubis Ungu (Brassica Oleraceae) Sebagai Indikator Warna Pada Analisis Hidrokuinon," Akta Kim. Indones., vol. 4, no. 2, p. 95, 2019, doi: 10.12962/j25493736.v4i2.5134.

[12] B. Wiyantoko and A. Astuti, "Butterfly Pea (Clitoria Ternatea L.) Extract as Indicator of Acid-Base Titration," IJCA (Indonesian J. Chem. Anal., vol. 3, no. 1, pp. 22-32, 2020, doi: 10.20885/ijca.vol3.iss1.art4.

[13] A. D. M. Anam Khairul, Widiyandari Hendri, "Jurnal Kimia Sains dan Aplikasi Identifikasi dan Kuantifikasi Antosianin dari Fraksi Bunga Rosela," J. Kim. Sains dan Apl., vol. 19, no. 2, pp. 50-57, 2016.

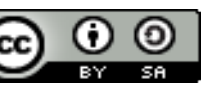

Jurnal IJCA is licensed under aÂ Creative Commons Attribution ShareAlike 4.0 